\title{
Techno-Functional Quality of Little Millet Composite Bread Supplemented with Soy Flour
}

\author{
Priyadarshani Deshmukh* and Nirmala Yenagi
}

Department of Food Science and Nutrition, College of Rural Home Science, University of Agricultural Sciences, Dharwad, India

*Corresponding author

\section{A B S T R A C T}

\begin{tabular}{|l|}
\hline K e y w o r d s \\
Gluten, Little millet, \\
Nutritional quality, \\
$\begin{array}{l}\text { Soy, Techno- } \\
\text { functional quality. }\end{array}$ \\
\hline Article Info \\
\hline $\begin{array}{l}\text { Accepted: } \\
\text { 23 October } 2017 \\
\text { Available Online: } \\
\text { 10 December } 2017\end{array}$ \\
\hline
\end{tabular}

Bread with $30 \%$ little millet flour was developed. Further 5\% soy flour and $10 \%$ gluten was incorporated in millet composite flour by replacing wheat flour and developed breads were analyzed for physical, textural, sensory and nutritional quality. Wheat bread was superior in specific volume, texture and sensory quality. Texture of little millet bread improved on addition of soy and gluten with significant decrease in the hardness. Sensory quality of soy and gluten incorporated bread was on par with little millet composite bread. On addition of little millet; fat, dietary fibre, total phenols and antioxidant activity content of wheat bread was enhanced. Soy and gluten supplementation showed further enhancement in the protein, dietary fibre, ash, phenolics and antioxidant activity. Supplementation of non-gluten flours enriched the nutritional quality of wheat bread and would meet the demand of population for nutrient dense bread with good acceptability.

\section{Introduction}

Recently with the modernization and changing food habits the consumption of convenient ready to eat (RTE) cereal foods is increasing throughout the world and bread has become a staple food of the modern diet. Traditionally bread is made from refined wheat flour. Apart from being a good source of calories and other nutrients, wheat is considered nutritionally poor, as the cereal proteins are deficient in essential amino acids such as lysine and threonine.

The consumption of bread and other baked goods produced from refined wheat flour is very popular, but the low protein content of wheat flour, which is the most vital ingredient used for the production of different kinds of baked goods has been major concern in its utilization (Young, 2001). Supplementation of wheat flour with inexpensive staples, such as cereals and pulses helps in improving the nutritional quality of wheat products.

The use of composite flours for product development and / or for value addition is also recent development across the globe owing to some health, economic and social reasons as well as increased demand for nutritious products. Utilization of locally grown cereals in baking industry is an additional advantage for the farmers to have more economic value to crop, better remuneration, value addition and diversified health products. 
Millets are indigenous small seeded cereals that, unlike wheat or rice can be cultivated in semi-arid and subtropical agronomic conditions throughout the world. Millets are rich in vitamins, minerals, sulphur containing amino acids and phytochemicals, and hence are termed as "nutri-cereals". They have higher proportions of non-starchy polysaccharides and dietary fibres thus have a low glycemic index (Chhavi and Sarita, 2012). Soybean is an excellent source of protein $(35-40 \%)$, hence the seed is the richest in food value of all plant foods consumed in the world (Olaoye et al., 2006). It is also rich in calcium, iron, phosphorus and vitamins. It is the only source that contains all the essential amino acids (Olaoye et al., 2006). Several researchers have investigated the effect of supplementation of wheat flour with soy and other legume flours for making products such as bread (Dhingra and Jood 2001; Olaoye et al., 2006; Abioye et al., 2011; Ndife et al., 2011). Replacement of refined wheat flour with millet flour upgrades the nutritional quality of bread and up to 30 to 50 per cent millet flours can be incorporated in bread without affecting its sensory qualities (Chhavi and Sarita, 2012; Mannuramath, et al., 2015 and Ballolli et al., 2014 respectively). The benefits of these composite flours are largely centered on nutritional considerations.

Recently, consumers' awareness of the need to eat high quality and healthy foods - known as functional foods, that is, foods which contain ingredients that provide additional health benefits beyond the basic nutritional requirements, is increasing (Ndife and Abbo, 2009). Therefore, the trend is to produce specialty breads made from whole grain flour and other functional ingredients known as health breads or functional foods (Dewettinck et al., 2008). Hence, the purpose of this investigation was to characterize the effect of soy addition on the quality of little millet flour bread. Composite flours affect baking and sensory quality of breads. Therefore to counteract the deleterious effects of legume flour in composite breads, additions of gluten have also been evaluated.

\section{Materials and Methods}

Little millet (Panicum miliare) grains and other ingredients viz., refined wheat flour (supermoti), germinated soy flour (Manna), sugar, salt, sunflower oil and dry yeast (Gloripan) were procured from the local market of Dharwad. Gluten was procured from the local market of Nashik. Little millet grains were cleaned washed and milled into flour.

\section{Preparation of composite flours}

Little millet flour was blended at 30 per cent level with refined wheat flour to develop little millet composite flour. Further, 5 per cent soy flour and 10 per cent gluten was added in the developed little millet composite flour by replacing wheat flour.

\section{Method of preparation of bread}

A standard method of preparation of bread given by (Mannuramath et al., 2015) was followed for the refined wheat flour bread. Ingredients used for bread making were $150 \mathrm{~g}$ flour, $2.25 \mathrm{~g}$ dry yeast, $9 \mathrm{~g}$ sugar, $7.5 \mathrm{~g}$ oil and $2.4 \mathrm{~g}$ salt. An adequate amount of water was used to obtain dough of optimum consistency. Optimized method of little millet composite bread for processing conditions was used to prepare composite breads (Deshmukh and Yenagi, 2016).

\section{Physical quality characteristics of bread}

Bread loaves were weighed $2 \mathrm{hr}$ after baking, using a laboratory scale balance and the readings recorded in grams. Height, length 
and width of the bread loaves were measured by measuring scale. The loaf volume was determined using seed displacement method. Specific volume was calculated as volume to mass ratio $\left(\mathrm{cm}^{3} / \mathrm{g}\right)$.

\section{Texture analysis}

Instrumental Texture Profile Analysis (TPA) of bread was performed with a TA.XT2i Texture Analyzer (Stable Micro Systems, Surrey, UK). The selected settings were mode- Measure force in compression, optionreturn to start, Pre-Test speed-1.00 mm.s $\mathrm{s}^{-1}$ Test speed- $1.7 \mathrm{~mm} / \mathrm{s}^{-1}$, Post-Test speed - 10 $\mathrm{mm} / \mathrm{s}^{-1}$, Distance $-5 \mathrm{~mm}$, time-30 sec, trigger force- Auto-5g, tare mode- Auto, data acquisition rate- $250 \mathrm{pps}$, probe- $35 \mathrm{~mm}$ end aluminium compression disc (Probe $\mathrm{P} / 35$ ). TPA was carried out using Texture Export Exceed software. Triplicate measurements were made for all breads.

\section{Colour measurement}

Colour of the bread samples was measured using a Hunter Lab Colorimeter. Hunter lab colorimeter value $\mathrm{L}^{*}$ (0-black, 100- white), $\mathrm{a}^{*}$ (+ value - red, -ve value- green) and $b^{*}(+$ value- yellow, -value-blue) were recorded.

\section{Sensory quality evaluation of bread}

Sensory evaluation of bread was carried out by ten member trained panel of Food Science and Nutrition department using 9 point hedonic scale. The rating was ranged from 9like extremely to 1-dislike extremely.

\section{Nutritional analysis of bread}

Bread samples were analyzed for moisture, protein, fat and ash content by using standard methods (AOAC 2000). Carbohydrate content of bread samples was calculated by difference method. Dietary fibre was estimated by gravimetric, enzymatic method (Asp et al., 1983). Total phenol estimation was carried out with the Folin-Ciocalteau reagent. Gallic acid was used as the standard. The DPPH scavenging activity assay of bread samples was carried out according to the procedure given by Yu et al., (2002).

\section{Statistical analysis}

A minimum of three replications were performed for each analysis. Statistical analysis was conducted to compare treatment means by using one way ANOVA procedure of SPSS software, version 16.0.

\section{Results and Discussion}

\section{Physical characteristics}

Significant $(P<0.05)$ differences were noticed in the loaf weight, volume and specific volume, whereas, changes found in the loaf height, width and length were statistically non-significant (Table 1).

Refined wheat flour bread showed significantly higher specific volume than the little millet composite and soy flour and gluten incorporated little millet composite bread (Fig. 1). This may be due to dilution of gluten with the incorporation of non-gluten flours. The obtained results confirmed the data presented by Sadowska et al., (2003) who found that the addition of germinated pea flour resulted in decreased volume of bread.

Frank et al., (2006) previously reported that volume of bread decreased with increased addition of grains (flax seed flour at $15 \%$ level and soy flour at 5 and $10 \%$ level). Dhingra and Jood (2001) have also reported the decline in the specific volume of soy flour incorporated wheat breads; and concluded that 15 per cent soy flour addition was organoleptically acceptable. 
Table.1 Physical characteristics of soy flour and gluten incorporated bread

\begin{tabular}{|c|c|c|c|c|c|c|}
\hline Breads & $\begin{array}{c}\text { Loaf weight } \\
\text { (g) }\end{array}$ & $\begin{array}{c}\text { Loaf } \\
\text { height } \\
\text { (cm) }\end{array}$ & $\begin{array}{c}\text { Loaf } \\
\text { width } \\
(\mathrm{cm})\end{array}$ & $\begin{array}{c}\text { Loaf } \\
\text { length } \\
(\mathrm{cm})\end{array}$ & $\begin{array}{l}\text { Loaf volume } \\
\qquad\left(\mathrm{cm}^{3}\right)\end{array}$ & $\begin{array}{l}\text { Specific } \\
\text { volume } \\
\left(\mathrm{cm}^{3} / \mathrm{g}\right)\end{array}$ \\
\hline RWC & $119.84^{\mathrm{b}} \pm 1.43$ & $6.15^{\mathrm{a}} \pm 0.37$ & $5.73^{\mathrm{a}} \pm 0.27$ & $12.87^{\mathrm{a}} \pm 0.43$ & $421.33^{\mathrm{a}} \pm 4.76$ & $3.52^{\mathrm{a}} \pm 0.04$ \\
\hline LMC & $121.07^{\mathrm{b}} \pm 1.75$ & $5.58^{\mathrm{a}} \pm 0.53$ & $6.02^{\mathrm{a}} \pm 0.22$ & $12.98^{\mathrm{a}} \pm 0.58$ & $377.42^{\mathrm{b}} \pm 4.20$ & $3.12^{\mathrm{b}} \pm 0.11$ \\
\hline LMSG & $125.12^{\mathrm{a}} \pm 1.15$ & $5.55^{\mathrm{a}} \pm 0.58$ & $5.92^{\mathrm{a}} \pm 0.45$ & $12.97^{\mathrm{a}} \pm 0.39$ & $373.33^{\mathrm{b}} \pm 4.08$ & $2.98^{c} \pm 0.03$ \\
\hline F value & 21.259 & 2.708 & 1.126 & 0.109 & 209.406 & 92.278 \\
\hline S.Em \pm & 0.60 & 0.20 & 0.14 & 0.19 & 1.78 & 0.03 \\
\hline CD (5\%) & 1.80 & NS & $\mathrm{NS}$ & $\mathrm{NS}$ & 5.36 & 0.09 \\
\hline
\end{tabular}

${ }^{a}$ NS- Non significant, Mean \pm SD, RWC- Refined wheat flour control, LMC- Little millet composite, LMSG- Little millet soy gluten, Means with the same superscript letters within a column are not significantly different at $5 \%$ level

Table.2 Textural quality of soy flour and gluten incorporated bread

\begin{tabular}{|l|c|c|c|c|c|c|}
\hline Breads & $\begin{array}{c}\text { Hardness } \\
(\mathbf{N})\end{array}$ & Springiness & Cohesiveness & $\begin{array}{c}\text { Gumminess } \\
(\mathbf{N})\end{array}$ & $\begin{array}{c}\text { Chewiness } \\
(\mathbf{N})\end{array}$ & Resilience \\
\hline RWC & $7.93^{\mathrm{c}} \pm 0.10$ & $0.93^{\mathrm{b}} \pm 0.00$ & $0.71^{\mathrm{a}} \pm 0.03$ & $5.94^{\mathrm{b}} \pm 0.13$ & $5.33^{\mathrm{b}} \pm 0.24$ & $0.39^{\mathrm{a}} \pm 0.03$ \\
\hline LMC & $15.51^{\mathrm{a}} \pm 0.60$ & $0.91^{\mathrm{c}} \pm 0.01$ & $0.51^{\mathrm{b}} \pm 0.01$ & $7.60^{\mathrm{a}} \pm 0.13$ & $6.76^{\mathrm{a}} \pm 0.21$ & $0.26^{\mathrm{b}} \pm 0.04$ \\
\hline LMSG $^{\mathrm{a}} \pm 10.94^{\mathrm{b}} \pm 0.74$ & $0.96^{\mathrm{a}} \pm 0.00$ & $0.67^{\mathrm{a}} \pm 0.01$ & $7.50^{\mathrm{a}} \pm 0.50$ & $7.21^{\mathrm{a}} \pm 0.30$ & $0.29^{\mathrm{b}} \pm 0.04$ \\
\hline F value & 95.271 & 42.931 & 78.040 & 27.366 & 45.579 & 13.489 \\
\hline S.Em \pm & 0.374 & 0.005 & 0.005 & 0.177 & 0.144 & 0.025 \\
\hline CD $(\mathbf{5 \%})$ & 1.29 & 0.02 & 0.02 & 0.62 & 0.50 & 0.09 \\
\hline
\end{tabular}

${ }^{a}$ RWC-Refined wheat flour control, LMC-Little millet composite, LMSG- Little millet soy gluten, Mean \pm SD, Means with the same superscript letters within a column are not significantly different at $5 \%$ level

Table.3 Mean crust and crumb colour values of soy flour and gluten incorporated bread

\begin{tabular}{|l|c|c|c|c|c|c|}
\hline \multirow{2}{*}{ Breads } & \multicolumn{3}{|c|}{ Crust } & \multicolumn{3}{c|}{ Crumb } \\
\cline { 2 - 7 } & $\mathbf{L}^{*}$ & $\mathbf{a}^{*}$ & $\mathbf{b}^{*}$ & $\mathbf{L}^{*}$ & $\mathbf{a}^{*}$ & $\mathbf{b}^{*}$ \\
\hline RWC & $39.89^{\mathrm{b}} \pm 0.16$ & $19.27^{\mathrm{b}} \pm 0.04$ & $25.12^{\mathrm{b}} \pm 0.12$ & $74.28^{\mathrm{a}} \pm 1.00$ & $1.15^{\mathrm{c}} \pm 0.03$ & $18.17^{\mathrm{b}} \pm 0.15$ \\
\hline LMC & $33.99^{\mathrm{c}} \pm 0.03$ & $17.85^{\mathrm{c}} \pm 0.05$ & $20.75^{\mathrm{c}} \pm 0.10$ & $73.24^{\mathrm{a}} \pm 0.39$ & $1.41^{\mathrm{b}} \pm 0.03$ & $18.26^{\mathrm{b}} \pm 0.05$ \\
\hline LMSG & $40.41^{\mathrm{a}} \pm 0.42$ & $19.89^{\mathrm{a}} \pm 0.06$ & $28.25^{\mathrm{a}} \pm 0.42$ & $69.19^{\mathrm{b}} \pm 0.85$ & $2.64^{\mathrm{a}} \pm 0.09$ & $18.70^{\mathrm{a}} \pm 0.05$ \\
\hline F value & 565.641 & 1346 & 635.827 & 34.566 & 556.99 & 16.588 \\
\hline S.Em \pm & 0.14 & 0.02 & 0.14 & 0.45 & 0.03 & 0.06 \\
\hline CD $(\mathbf{5 \%})$ & 0.52 & 0.08 & 0.51 & 1.58 & 0.10 & 0.23 \\
\hline
\end{tabular}

${ }^{a}$ RWC- Refined wheat flour control, LMC- Little millet composite, LMSG- Little millet soy gluten, Mean \pm SD, Means with the same superscript letters within a column are not significantly different at $5 \%$ level 
Table.4 Sensory quality of soy flour and gluten incorporated bread

\begin{tabular}{|l|c|c|c|c|c|c|c|c|c|}
\hline Breads & Appearance & $\begin{array}{c}\text { Crust } \\
\text { colour }\end{array}$ & $\begin{array}{c}\text { Crumb } \\
\text { colour }\end{array}$ & Taste & $\begin{array}{c}\text { Crust } \\
\text { texture }\end{array}$ & $\begin{array}{c}\text { Crumb } \\
\text { texture }\end{array}$ & $\begin{array}{c}\text { Flavour } \\
\text { Mouth } \\
\text { feel }\end{array}$ & $\begin{array}{c}\text { Overall } \\
\text { acceptability }\end{array}$ \\
\hline RWC & $8.9^{\mathrm{a}} \pm 0.32$ & $8.6^{\mathrm{a}} \pm 0.52$ & $8.8^{\mathrm{a}} \pm 0.42$ & $8.4^{\mathrm{a}} \pm 0.52$ & $8.6^{\mathrm{a}} \pm 0.52$ & $8.9^{\mathrm{a}} \pm 0.32$ & $8.5^{\mathrm{a}} \pm 0.71$ & $8.1^{\mathrm{a}} \pm 0.42$ & $8.4^{\mathrm{a}} \pm 0.32$ \\
\hline LMO & $7.4^{\mathrm{b}} \pm 0.70$ & $7.6^{\mathrm{b}} \pm 0.79$ & $7.7^{\mathrm{b}} \pm 0.48$ & $8.1^{\mathrm{a}} \pm 0.67$ & $7.3^{\mathrm{b}} \pm 0.74$ & $7.4^{\mathrm{b}} \pm 0.84$ & $7.6^{\mathrm{b}} \pm 0.84$ & $7.4^{\mathrm{b}} \pm 0.97$ & $7.8^{\mathrm{b}} \pm 0.63$ \\
\hline LMSG & $7.5^{\mathrm{b}} \pm 0.71$ & $7.7^{\mathrm{b}} \pm 0.48$ & $7.5^{\mathrm{b}} \pm 0.85$ & $7.1^{\mathrm{b}} \pm 0.74$ & $7.6^{\mathrm{b}} \pm 0.52$ & $7.6^{\mathrm{b}} \pm 0.52$ & $7.4^{\mathrm{b}} \pm 0.70$ & $7.4^{\mathrm{b}} \pm 0.52$ & $7.4^{\mathrm{b}} \pm 0.70$ \\
\hline F value & 19.37 & 13.45 & 12.97 & 10.03 & 20.32 & 18.46 & 6.06 & 14.23 & 18.03 \\
\hline S.Em \pm & 0.24 & 0.24 & 0.25 & 0.26 & 0.18 & 0.24 & 0.30 & 0.20 & 0.23 \\
\hline $\begin{array}{l}\text { CD } \\
(\mathbf{5 \%})\end{array}$ & 0.71 & 0.72 & 0.73 & 0.77 & 0.56 & 0.71 & 0.89 & 0.70 & 0.68 \\
\hline
\end{tabular}

${ }^{a}$ RWC- Refined wheat flour control, LMC-Little millet composite, LMSG- Little millet soy gluten, Mean \pm SD,

Means with the same superscript letters within a column are not significantly different at $5 \%$ level

Table.5 Nutrient composition of soy and gluten incorporated bread

\begin{tabular}{|c|c|c|c|c|c|c|c|c|c|c|}
\hline $\begin{array}{l}\text { Bread } \\
\text { S }\end{array}$ & $\begin{array}{c}\text { Moisture } \\
\text { (g/100g) }\end{array}$ & $\begin{array}{l}\text { Protein } \\
\text { (g/100g) }\end{array}$ & $\begin{array}{c}\text { Fat } \\
(\mathrm{g} / \mathbf{1 0 0 g})\end{array}$ & $\begin{array}{c}\text { SDF } \\
(\mathrm{g} / 100 \mathrm{~g})\end{array}$ & $\begin{array}{c}\text { IDF } \\
(\mathrm{g} / \mathbf{1 0 0 g})\end{array}$ & $\begin{array}{c}\text { TDF } \\
(\mathrm{g} / 100 \mathrm{~g})\end{array}$ & $\begin{array}{c}\text { Ash } \\
(\mathrm{g} / \mathbf{1 0 0 g})\end{array}$ & $\begin{array}{c}\text { Carbohydra } \\
\text { te } \\
(\mathrm{g} / \mathbf{1 0 0 g})\end{array}$ & $\begin{array}{c}\text { Total } \\
\text { phenols } \\
(\mathrm{mg} / \mathbf{1 0 0 g})\end{array}$ & $\begin{array}{c}\text { Antioxida } \\
\text { nt activity } \\
(\%)\end{array}$ \\
\hline RWC & $\begin{array}{c}32.82^{\mathrm{ab}} \pm 0 \\
92\end{array}$ & $\begin{array}{c}12.70^{\mathrm{b}} \pm 0 \\
21\end{array}$ & $\begin{array}{c}2.73^{\mathrm{a}} \pm 0.0 \\
7\end{array}$ & $\begin{array}{c}1.03^{\mathrm{c}} \pm 0.0 \\
6\end{array}$ & $\begin{array}{c}1.77^{\mathrm{c}} \pm 0.0 \\
6\end{array}$ & $\begin{array}{c}2.80^{\mathrm{b}} \pm 0 \\
10\end{array}$ & $\begin{array}{c}2.03^{\mathrm{b}} \pm 0 \\
03\end{array}$ & $44.12^{a} \pm 0.85$ & $\begin{array}{c}20.56^{\mathrm{c}} \pm 1 \\
03\end{array}$ & $\begin{array}{c}17.09^{c} \pm 0.5 \\
5\end{array}$ \\
\hline LMC & $\begin{array}{c}31.85^{\mathrm{b}} \pm 0.5 \\
3\end{array}$ & $\begin{array}{c}11.70^{\mathrm{c}} \pm 0 \\
10\end{array}$ & $\begin{array}{c}3.29^{\mathrm{a}} \pm 0.1 \\
2\end{array}$ & $\begin{array}{c}1.98^{\mathrm{b}} \pm 0 \\
02\end{array}$ & $\begin{array}{c}6.40^{\mathrm{a}} \pm 0.0 \\
9\end{array}$ & $\begin{array}{c}8.39^{\mathrm{a}} \pm 0.1 \\
1\end{array}$ & $\begin{array}{c}2.23^{\mathrm{b}} \pm 0 \\
04\end{array}$ & $34.67^{\mathrm{b}} \pm 0.90$ & $\begin{array}{c}34.45^{\mathrm{b}} \pm 0 \\
20\end{array}$ & $\begin{array}{c}23.26^{b} \pm 0.6 \\
7\end{array}$ \\
\hline $\begin{array}{l}\text { LMS } \\
\text { G }\end{array}$ & $\begin{array}{c}33.89^{\mathrm{a}} \pm 0.8 \\
5\end{array}$ & $\begin{array}{c}13.58^{\mathrm{a}} \pm 0 \\
24\end{array}$ & $\begin{array}{c}1.52^{\mathrm{b}} \pm 0 \\
58\end{array}$ & $\begin{array}{c}3.03^{\mathrm{a}} \pm 0.1 \\
2\end{array}$ & $\begin{array}{c}5.50^{\mathrm{b}} \pm 0 \\
10\end{array}$ & $\begin{array}{c}8.54^{\mathrm{a}} \pm 0.0 \\
5\end{array}$ & $\begin{array}{c}2.34^{\mathrm{a}} \pm 0.0 \\
7\end{array}$ & $31.60^{c} \pm 0.37$ & $\begin{array}{c}42.04^{\mathrm{a}} \pm 0 \\
42\end{array}$ & $\begin{array}{c}39.28^{\mathrm{a}} \pm 0.8 \\
4\end{array}$ \\
\hline $\begin{array}{l}\text { F } \\
\text { value }\end{array}$ & 5.036 & 71.442 & 20.541 & 526.754 & 2657 & 3830 & 49.104 & 240.553 & 826.128 & 734.455 \\
\hline SEm \pm & 0.45 & 0.11 & 0.20 & 0.04 & 0.05 & 0.05 & 0.03 & 0.04 & 0.38 & 0.40 \\
\hline $\begin{array}{l}\text { CD } \\
(5 \%)\end{array}$ & 1.57 & 0.38 & 0.69 & 0.15 & 0.17 & 0.18 & 0.09 & 1.47 & 1.31 & 1.42 \\
\hline
\end{tabular}

${ }^{a}$ RWC-Refined wheat flour control, LMC-Little millet composite, LMSG- Little millet soy gluten, Mean \pm SD, Means with the same superscript letters within a column are not significantly different at $5 \%$ level 
Fig.1 Top and cross sectional view of refined wheat, little millet composite and soy flour and gluten incorporated breads

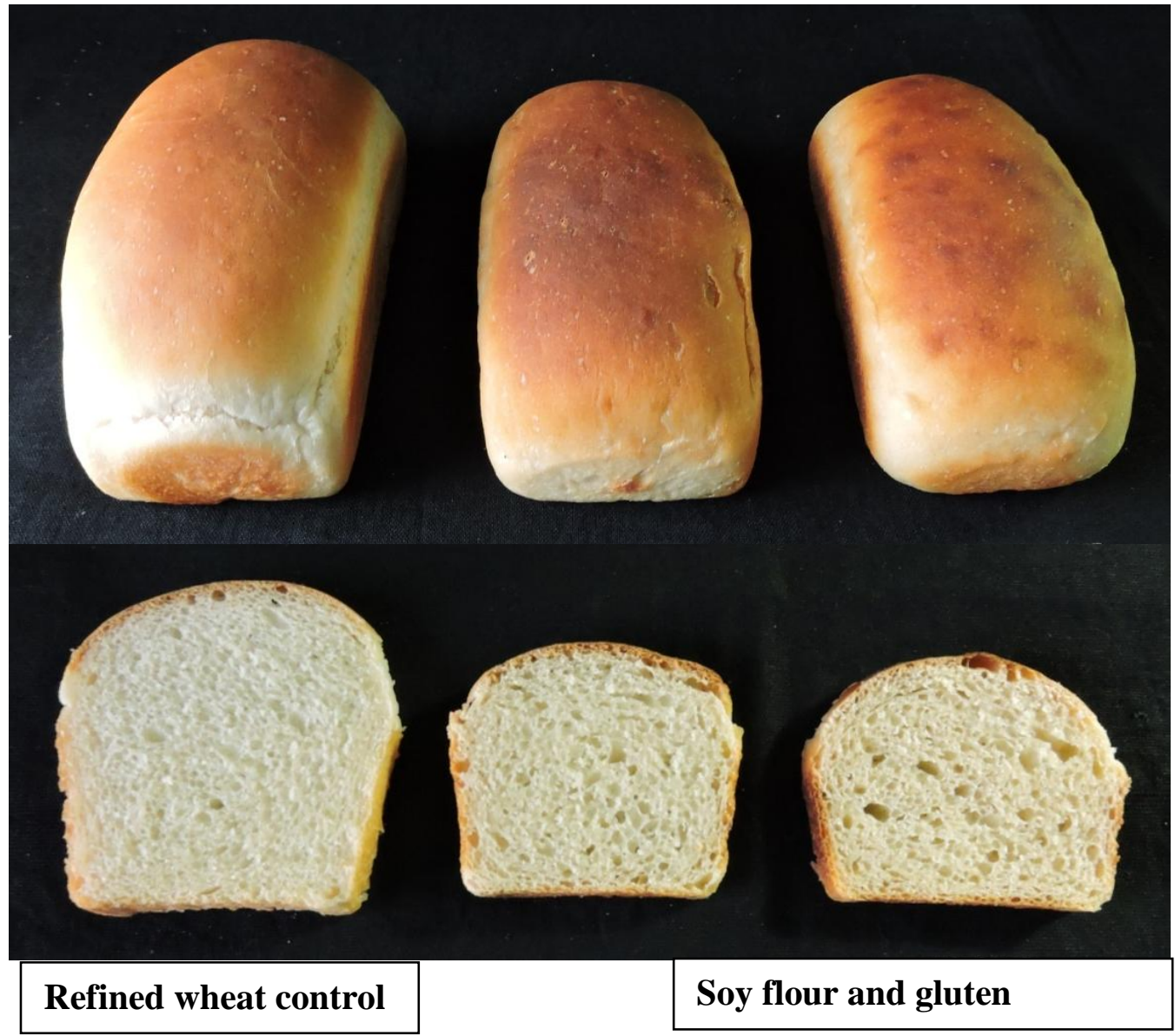

\section{Little millet}

\section{Textural quality}

Incorporation of germinated soy flour and gluten showed significant improvement in the textural quality of little millet composite flour bread (Table 2). Hardness, springiness and cohesiveness values were significantly improved with the incorporation of germinated soy flour and gluten in the little millet composite flour bread.

Though the differences were not significant gumminess and resilience was also improved. This may be due to increase in the soluble dietary fibre content of this bread (Table 5) with increase in the WAC (data not shown) of germinated soy flour and possibly may be the reflection of gluten incorporation.

\section{Colour of bread crust and crumb}

Significant differences were noticed in the colour of breads (Table 3). Incorporation of soy flour and gluten significantly increased the $\mathrm{L}^{*}, \mathrm{a}^{*}$ and $\mathrm{b}^{*}$ values of crust and $\mathrm{a}^{*}$ and $b^{*}$ values of crumb with significant decrease in the $\mathrm{L}^{*}$ value of crumb. This was also reflected in the sensory scores of these breads which shown that higher scores for crust with decreased scores for crumb colour. Doxastakis et al., (2002) reported darkened crust colour and increased yellowness of 
bread crumb with addition of soy flour at 5 to 10 percent level.

\section{Sensory quality of bread}

The mean sensory scores of refined wheat flour bread for appearance were significantly high (8.9) when compared with little millet bread (7.4) and soy and gluten added bread (7.5) (Table 4). Sensory scores of crust and crumb colour of refined wheat flour were 8.6 and 8.8 respectively. Addition of soy flour and gluten showed positive effect on the crust colour of bread with the mean sensory score of (7.7). No significant difference was observed in the taste scores of refined wheat bread and little millet bread. Taste score of soy flour and gluten incorporated breads were found to be declined significantly when compared with the little millet composite bread (8.1). This may be due to the beany flavour of the soy flour. Texture of little millet composite bread was improved with the addition of soy flour and gluten. No significant difference was seen in the overall acceptability of refined wheat flour and little millet flour and later with that of soy and gluten added bread. The sensory analysis results were similar to those reported by Dooshima et al., (2014) for wheat, soy and banana composite flour bread.

\section{Nutrient composition of breads}

Significant difference $(\mathrm{p}<0.05)$ was observed in the moisture content of refined wheat flour, little millet flour and little millet soy flour and gluten incorporated breads with a mean per cent moisture content of $32.82,31.85$ and 33.89 per cent respectively (Table 5). The protein content of refined wheat flour bread was $(12.70 \%)$ which was declined to 11.70 per cent in case of little millet flour bread. However, incorporation of soy flour and gluten showed significantly higher protein content $(13.58 \%)$. These results were in agreement with those reported by Dhingra and Jood 2001 who found that protein content of composite bread decreased upon supplementation of barley flour, which was increased with incorporation of soy flour in the flour blend. The fat content for refined wheat flour bread was 2.73 per cent, which increased significantly to 3.29 per cent on blending with little millet flour. A significant decrease was observed in fat content for soy flour and gluten incorporated bread (1.52\%). This could be attributed to the fat content of these flours (data not shown). All the dietary fibre components increased significantly $(\mathrm{P}<0.05)$ on blending of little millet flour at 30 percent level in the refined wheat flour. Soluble, insoluble and total dietary fibre content of soy flour and gluten incorporated bread were $3.03,5.50$ and 8.54 per cent respectively; which further enriched the dietary fibre content of little millet composite flour bread. Ash content of breads varied significantly with the highest $(2.34 \%)$ being for soy and gluten added breads and lowest was found in refined wheat flour bread (2.03\%), while the little millet composite bread had ash content of 2.23 per cent. The highest carbohydrate content was seen in refined wheat flour bread with a mean per cent value of 44.12. Incorporation of soy flour and gluten showed significant decrease $(31.60 \%)$ in the carbohydrate content of bread. Total phenol content of soy and gluten added bread was significantly higher than refined wheat flour and little millet composite flour breads. Significantly higher DPPH scavenging activity was exhibited by soy and gluten added breads compared to refined wheat and little millet composite breads. Overall; nutritional quality viz., protein, dietary fibre and ash content of the soy flour and gluten added bread was found to be superior in comparison with refined wheat flour as well as little millet composite bread. Similarly Dhingra and Jood (2001) reported increase in the protein, fat and ash content of 
bread with addition of soy flour at different levels. Significant change was also reported in soluble dietary fibre contents of wheat breadsupplemented with barley plus full fat soy and barley plus defatted soy flours (Dhingra and Jood, 2001).

Wheat flour bread had significantly higher specific volume with better acceptability than the composite breads. Nevertheless, nutritional quality of little millet composite bread was superior to that of wheat flour bread which was further enriched with supplementation of soy flour at 5 per cent level and 10 per cent gluten. Textural quality of little millet composite flour bread improved significantly as an effect of soy flour and gluten addition. Supplementation of non-gluten flours like millet and soy enriched the nutritional quality of wheat bread. Such functional breads would meet the demand of general population for nutrient dense bread and may help those suffering from metabolic disorders being a healthy choice with good acceptability.

\section{Acknowledgement}

The first author wishes to acknowledge the Dept. of Science and Technology, New Delhi for providing financial support in the form of Inspire Fellowship to carry out this research work.

\section{References}

Abioye, V. F., Ade-Omowaye, B. I. O., Babarinde, G. O. and Adesigbin, M. K. 2011. Chemical, physico-chemical and sensory properties of soy-plantain flour. Afr. J. Food Sci., 5(4): 176 - 180.

AOAC. 2000. Official Methods of Analysis, $20^{\text {th }}$ edn. Association of Official Analytical Chemists, Washington, DC.

Asp, N. G., Johansson, C. G., Hallmer, H. and Silgestrom, M. 1983. Rapid enzymatic assay of insoluble and soluble dietary fiber. J. Agric. Food Chem., 31: 476482.

Ballolli, U., Malagi, U., Yenagi, N., Orsat, V. and Gariepy, Y. 2014. Development and quality evaluation of foxtail millet [Setaria italic (L.)] incorporated breads. Karnataka J. Agric. Sci., 27 (1): 52-55.

Chhavi, A. and Sarita, S. 2012. Evaluation of composite millet breads for sensory and nutritional qualities and glycemic response. Mal. J. Nutr., 18 (1): 89-101.

Dewettinck, K., Bockstaele, V. F., Kuhne, B., Walle, V., Courtens, T. andGellynck, X. 2008. Nutritional value of bread: Influence of processing, food interaction and consumer perception. Rev. J. Cereal Sci., 48: 243-257.

Dhingra, S. and Jood, S. 2001. Organoleptic and nutritional evaluation of wheat breads supplemented with soybean and barley flour. Food Chem., 77: 479-488.

Dooshima, I. B., Julius, A. and Abah, O. 2014. Quality evaluation of composite bread produced from wheat, defatted soy and banana flours. Int. J. Nutr. Food Sci., 3(5): 471-476.

Doxastakis, G., Zafiriadis, I., Irakli, M., Marlani, $H$. and Tananak, C. 2002.Lupin, soya and triticale addition to wheat flour doughs and their effect on rheological properties. Food Chem., 77: 219-227.

Frank, D., Conforti and Davis, S. F. 2006. The effect of soya flour and flaxseed as a partial replacement for bread flour in yeast bread. Int., J. Food Sci. Technol., 41(2): 95-101.

Gopalan, C., Ramasastri, B.V. and Balaubramanian, S.C. 2010. Nutritive value of Indian foods. National Institute of Nutrition, ICMR, Hyderabad.

Mannuramath, M., Yenagi, N. and Valerie, O. 2015. Quality evaluation of little millet (Panicum miliare) incorporated 
functional bread. J. Food Sci. Technol., 52(12): 8357-8363.

Ndife, J. and Abbo, E. 2009. Functional Foods: Prospects and Challenges in Nigeria. J. Sci. Technol., 1(5): 1-6.

Ndife, J., Abdulraheem, L. O. and Zakari, U. M. 2011. Evaluation of the nutritional and sensory quality of functional breads produced from whole wheat and soya bean flour blends. Afr. J. Food Sci., 5(8): 466-472.

Olaoye O. A., Onilude A. A.and Idowu O. A. 2006. Quality characteristics of bread produced from composite flours of wheat, plantain and soybeans. Afr. J. Biotechnol. 5 (11): 1102-1106.

Priyadarshani, D. and Nirmala, Y. 2016. Optimization of processing conditions for improved physical and sensory attributes of little millet composite flour bread. J. Farm Sci., 29(4): 513-516.

Sadowska, J., Błaszczak, W., Fornal, J., Vidal-Valverde, C. and Frias, J. 2003. Changes of wheat dough and bread quality and structure as a resultof germinated pea flour addition. Eur Food Res Technol., 216: 46-50.

Young, J. 2001. Functional bakery products: current directions and future opportunities. Food Ind. J., 4: 136-144.

Yu, L., Haley, S., Perret, J., Harris, M., Wilson, J. and Qian, M. 2002. Free radical scavenging properties of wheat extracts. J. Agric. Food Chem., 50: 1619-1624.

\section{How to cite this article:}

Priyadarshani Deshmukh and Nirmala Yenagi. 2017. Techno-Functional Quality of Little Millet Composite Bread Supplemented with Soy Flour. Int.J.Curr.Microbiol.App.Sci. 6(12): 3077-3085. doi: https://doi.org/10.20546/ijcmas.2017.612.359 